JURNAL RISET MAHASISWA AKUNTANSI

http://ejournal.unikama.ac.id/index.php/jrma

JRMA, Volume 7 No 2, Oktober 2019

\title{
ANALISIS PENGARUH PENERAPAN ANGGARAN BERBASIS KINERJA, AKUNTABILITAS DAN TRANSPARANSI TERHADAP KINERJA KEUANGAN DAERAH KOTA MALANG
}

\author{
MARIA TRIMURNI ESNI
}

e-mail : mariaesni23@gmail.com

\author{
Anwar Made \\ Retno Wulandari \\ Program Studi Akuntansi, Fakultas Ekonomika dan Bisnis, Universitas Kanjuruhan \\ Malang
}

\begin{abstract}
ABSTRAK
Otonomi Daerah adalah hak, wewenang, dan kewajiban daerah otonom untuk mengatur dan mengurus sendiri urusan pemerintahan dan kepentingan masyarakat setempat sesuai dengan peraturan perundang-undangan. Pertimbangan mendasar terselenggaranya otonomi daerah adalah perkembangan kondisi di dalam negeri yang mengindikasikan bahwa semangkin maraknya globalisasi yang menuntut daya saing tiap Negara, termaksud daya saing pemerintah daerahnya. Penelitian ini bertujuan utuk mengetahui dan menganalisis pengaruh penerapan anggaran berbasis kinerja, akuntabilitas dan transparansi sebagai variabel independen baik secara parsial maupun simultan terhadap kinerja keuangan daerah Kota Malang. Penelitian ini menggunakan pendekatan kuantitatif dengan sampel sejumlah 44 pegawai pada OPD dan BPKAD Kota Malang. Pengukuran variabel dengan menggunakan Skala Likert dengan skor sampai 5. Data dianalisis dengan menggunakan analisis regresi linear berganda dan untuk menguji tingkat signifikan menggunakan uji $f$ dan uji hipotesis menggunakan uji t dengan bantuan program SPSS 22. Hasil secara parsial menunjukkan bahwa penerapan anggaran berbasis kinerja berpengaruh signifikan terhadap kinerja keuangan daerah, variabel akuntabilitas berpengaruh signifikan terhadap kinerja keuangan daerah dan variabel transparansi tidak berpengaruh terhadap kinerja keuangan daerah serta hasil penelitian secara simultan menunjukkan bahwa penerapan anggaran berbasis kinerja, akuntabilitas dan transparansi berpengaruh terhadap kinerja keuangan daerah.
\end{abstract}

Kata Kunci: penerapan anggaran berbasis kierja, akuntabilitas, transparansi dan kinerja keuangan daerah

\section{ABSTRACT}

Regional Autonomy is the right, authority and obligation of autonomous regions to regulate and manage their own government affairs and the interests of local communities in accordance with statutory regulations. The basic consideration of the implementation of regional autonomy is the development of conditions in the country that indicate that the rise of globalization that demands competitiveness of each country, including the competitiveness of local governments. This study aims to determine and analyze the effect of the implementation of performance-based budgeting, accountability and transparency as an independent variable both partially and simultaneously on the financial performance of the city of Malang. This study uses a quantitative approach with a sample of 44 employees in OPD and BPKAD Malang. Measurement of variables using a Likert Scale with a score of up to 5. Data were analyzed using multiple linear regression analysis and to test the significance level using the $f$ test and hypothesis testing using $t$ test with the help of the SPSS 22 program. Partial results indicate that the application of performance-based budgeting has a significant effect on regional financial performance, the accountability variable has a significant 
effect on regional financial performance and the transparency variable does not affect the regional financial performance and the results of research simultaneously show that the application of performance-based budgeting, accountability and transparency affects the regional financial performance

Keynotes: performance-based budgeting, accountability, transparency and financial performance

\section{PENDAHULUAN}

Otonomi daerah merupakan hak, wewenang, dan kewajiban daerah otonom untuk mengatur dan mengurus sendiri urusan pemerintah dan kepentingan masyarakat setempat sesuai dengan peraturan perudang-udangan (Simanjuntak, 2013). Sedangkan dana perimbangan merupakan sumber pendapatan daerah yang berasal dari APBN untuk mendukung pelaksanaan kewenanganpemerintah daerah dalam mencapai tujuan pemberian otonomi kepada daerah, terutama peningkatan pelayanan dan kesejaheraan masyarakat yang semakin baik (Mamuka dan Elim, 2014). Dengan adanya perimbangan keuangan antara pemerintah pusat dan daerah tersebut diperlukan sebuah laporan keuangan yang handal dan dapat dipercaya agar dapat menggambarkan sumber daya keuangan daerah dengan analisis prestasi pengelolaan sumber daya keuangan daerah tersebut, karena pemerintah pusat telah menyerahkan sumber daya keuangan kepada daerah dalam rangka peaksanaan otonomi daerah. Analisis prestasi dalam hal ini adalah kinerja dari pemerintah daerah itu sendiri yng dapat didasarkan pada kemandirian dan kemampuan untuk memperoleh, memiliki, memelihara dan memanfaatkan keterbatasan sumber ekonomis daerah untuk memenuhi kebutuhan masyarakat sepenuhnya di daerah tersebut. Mahmudi (2016) anggaran berbasis kinerja merupakan sistem penganggaran yang dilakukan dengan memperhatikan keterkaitan antara anggaran (input) dengan keluaran (output) dan hasil (outcome) yang diharapkan dari kegiatan dan program termasuk efisiensi dalam pencapaian keluaran dan hasil dari keluaran tersebut. Menurut Penny Kusumastuti (2014) akuntabilitas merupakan bentuk kewajiban penyedia penyelenggaraan kegiatan publik untuk dapat menjelaskan dan menjawab segala hal menyangkut langkah dari seluruh keputusan dan proses yang dilakukan, serta pertanggungjawaban terhadap hasil kinerjanya. Tahir (2011) transparansi merupakan keterbukaan dalam melaksanakan suatu proses kegiatan dan merupakan salah satu syarat penting untuk menciptakan good governance. Sularso (2011) kinerja keuangan merupakan suatu ukuran kinerja yang menggunakan indikator keuangan. Kinerja keuangan juga merupakan kemampuan dalam mengelola keuangan yang dituangkan dalam pendapatan belanja daerah yang baik secara langsung maupun tidak langsung mencerminkan kemampuan pemerintah daerah dalam membiayai pelaksanaan tugas-tugas pemerintah dan pelayanan sosial masyarakat.

\section{Tujuan Penelitian}

Berdasarkan masalah yang diuraikan tersebut, maka tujuan penelitian ini adalah untuk mengetahui dan menganalisis pengaruh penerapan anggaran berbasis kinerja, akuntabilitas dan transparansi terhadap kinerja keuangan daerah baik secara parsial maupun secara simultan.

\section{Tinjauan Pustaka}

\section{Peneraan anggaran berbasis kinerja}

Anggaran berbasis kinerja merupakan penganggaran bagi manajemen untuk mengaitkan setiap pendanaan yang dituangkan dalam kegiatan-kegiatan dengan keluaran dan hasil yang diharapkan termasuk efisiensi dalam pencapaian hasil dari keluaran tersebut (Halim 2012). Adapun indikator yang digunakan untuk mengukur anggaran berbasis kinerja adalah sebagai berikut, Pasolong (2013): 
a. Masukan

Merupakan segala sesuatu yang dibutuhkan untuk melaksanakan suatu kegiatan untuk menghasilkan keluaran atau memberikan pelayanan.

b. Keluaran

Merupakan produk atau keluaran langsung dari suatu aktivitas / kegiatanyang dilaksanakan.

c. Hasil

Menggambarkan hasil nyata dari keluaran suatu kegiatan dan mencerminkan berfungsinya keluaran tersebut.

d. Manfaat

Adalah sesuatu yang terkait dengan tujuan akhir dari pelaksanaan kegiatan.

e. Dampak

Merupakan pengaruh yang ditimbulkan baik positif maupun negatif terhadap setiap tingkatan indikator berdasarkan asumsi yang telah ditetapkan.

\section{Akuntabilitas}

Akuntabilitas merupakan kewajiban untuk memberikan pertanggungjawaban serta menerangkan kinerja dan tindakan seseorang atau pimpinan organisasi kepada pihak yang lain memiliki hak dan kewajiban untuk meminta kewajiban pertanggungjawaban dan keterangan (Halim, 2012). Adapun indikator akuntabilitas adalah sebagai berikut:

a) Penghindaran penyalahgunaan anggaran

b) Kepatuhan terhadap hukum

c) Proses dan pertanggungjawaban anggaran

d) Pertimbangantujuan dapat tercapai atau tidak dan hasil yang optimal dengan biaya yang minimal.

\section{Transparansi}

e) Pertanggungjawaban pemerintah kepada DPRD dan masyarakat

Transparansi merupakan keterbukaan dalam melaksanakan suatu proses kegiatan dan merupakan salah satu syarat penting untuk menciptakan good governance (Tahir, 2011). Adapun indikator transparansi adalah sebagai berikut:
a) Sistem keterbukaan kebijakan anggaran
b) Dokumen anggaran mudah diakses
c) Laporan pertanggungjawaban yang tepat waktu
d) Suara rakyat terakomodasi
e) Sistem pemberian informasi kepada publik

\section{Kinerja keuangan daerah}

Kinerja keuangan merupakan kemampuan dalam mengelola keuangan yang dituangkan dalam pendapatan belanja daerah yang baik secara langsung maupun tidak langsung mencerminkan kemampuan pemerintah daerah dalam membiayai pelaksanaan tugastugas pemerintah dan pelayanan sosial masyarakat (Sularso,2011). Adapun indikator kinerja keuangan adalah sebagai berikut:
a) Ekonomi
b) Efisiensi
c) Efektifitas

\section{Kerangka Konsep Peneletian}

Penelitian ini untuk mengetahui kerangka konsep pengaruh Penerapan Anggaran Berbasis Kinerja, akuntabilitas dan transparansi terhadap Kinerja Keuangan Daerah Kota Malang. Berdasarkan keterangan diatas, maka untuk mengetahui dan munguji adanya pengaruh penerapan anggaran berbasis kinerja, akuntabilitas dan transparansi terhadap kinerja keuangan daerah Kota Malang. Dikembangkan kerangka pemikiran yang 
dipaparkan maka dapat digambarkan kerangka pemikiran sebagai berikut:

Kerangka konseptual dalam penelitian ini dapat dilihat pada gambar berikut :

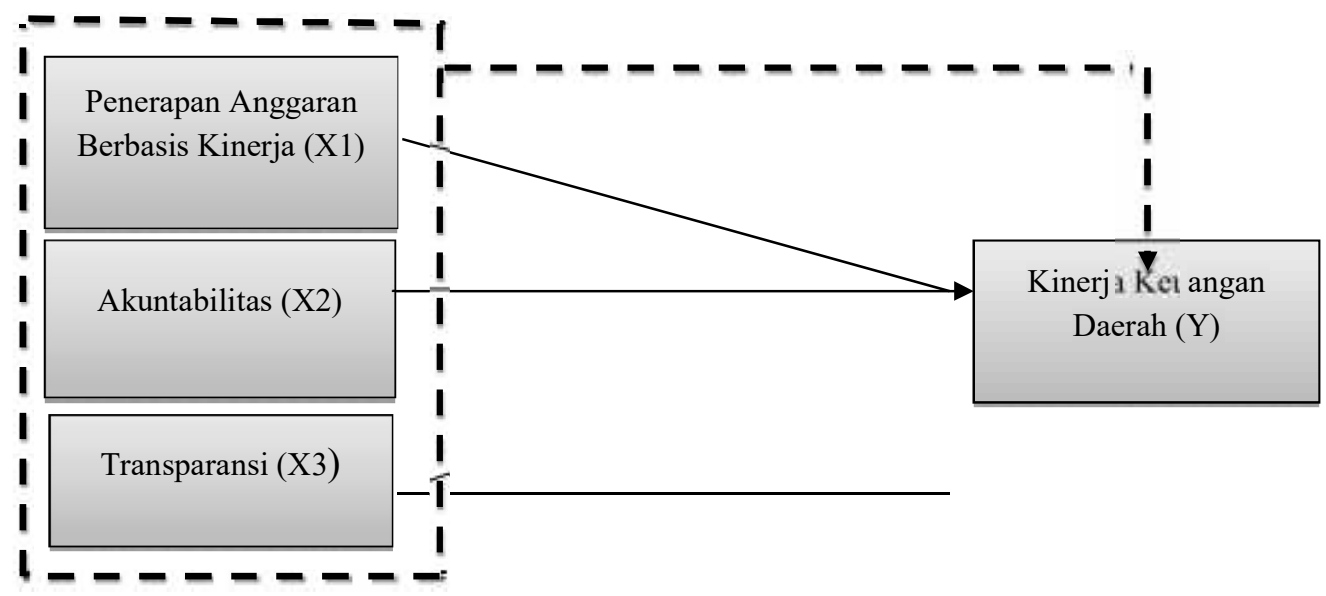

\section{Hipotesis}

Berdasarkan kerangka pemikiran diatas, maka hipotesis yang diajukan dalam penelitian ini adalah sebagai berikut:

$\mathrm{H}_{1}$ : Penerapan anggaran berbasis kinerja berpengaruh terhadap kinerja

keuangan $\mathrm{H}_{2}$ : Akuntabilitas berpengaruh terhadap kinerja keuangan

daerah

$\mathrm{H}_{3}$ : Transparansi berpengaruh terhadap kinerja keuangan daerah

$\mathrm{H}_{4}$ : Penerapan anggaran berbasis kinerja, akuntabilitas dan transparansi berpengaruh terhadap kinerja keuangan daerah

\section{Metode}

Metode yang digunakan dalam penelitian ini adalah metode penelitian kuantitatif berupa nilai atau skor atas jawaban yang diberikan oleh responden terhadap pernyataan yang ada dalam kuesioner. Populasi dalam penelitian ini adalah pegawai OPD dan pegawai BPKAD Kota Malang. Sedangkan sampel dalam penelitian ini adalah berjumlah 44. Pengambilan sampel dalam penelitian ini adalah teknik pengambilan sampel jenuh dimana seluruh anggota populasi digunakan sebagai sampel. Penelitian ini menggunakan analisis regresi linear berganda dan uji validitas serta uji rliabilitas, uji asumsi klasik, uji $\mathrm{f}$ dan uji hipotesis untuk menguji hipotesis yang telah dirumuskan.

\section{Pembahasan}

\section{Analisis}

\section{Deskriptif}

Berdasarkan hasil perhitungan statistik yang telah dilakukan, diperoleh ringkasan hasil analisis deskriptif sebagai berikut:

a) Hasil distribusi frekuensi variabel penerapan anggaran berbasis kinerja menunjukkan nilai rata-rata paling tinggi 6,89\% dengan menjawab setuju. Hal ini menunjukkan bahwa variabel penerapan anggaran berbasis kinerja Pemerintah Kota Malang sudah tercapai, hal ini didukung oleh indikator dari penerapan anggaran berbasis kinerja.

b) Hasil distribusi frekuensi variabel akuntabilitas menunjukkan nilai rata-rata paling tinggi 6,36\% dengan menjawab sangat setuju. Hasil ini menunjukkan bahwa akuntabilitas Pemerintah Kota Malang sudah tercapai dan hasil yang 
tinggi, dan didukung oleh indikator akuntabilitas.

c) Hasil distribusi frekuensi variabel transparansi menunjukkan nilai rata-rata paling tinggi sebesar 7,05\% dengan menjawab cukup setuju. Hal ini menunjukkan bahwa penerapan transparansi pada Pemerintah Kota Malang sudah tercapai dan didukung oleh indikator transparansi tersebut.

d) Hasil distribusi frekuensi variabel kinerja keuangan daerah menunjukkan nilai rata-rata paling tinggi sebesar $6,77 \%$ dengan menjawab setuju. Hal ini menunjukkan bahwa variabel kinerja keuangan daerah Kota Malang sudah tercapai dan didukung oleh indikator keuangan seperti ekonomis, efisiensi dan efektivitas.

\section{Hasil Uji Instrumen Uji Validitas}

Uji validitas digunakan untuk mengukur sah atau tidaknya suatu kuesioner. Suatu kuesioner dinyatakan valid jika pertanyaan pada kuesioner tersebut mampu untuk mengungkapkan suatu yang diukur oleh kuesioner tersebut. Jika rhitung lebih besar dari rtabel untuk degree of freedom (df) = n-2, dalam hal ini $\mathrm{n}$ adalah sampel. Jika rhitung lebih besar dari rtabel dan nilai positif mak butir pertanyaan atau indikator tersebut dinyatakan valid (Ghozali,2013). Pengujian validitas menggunakan Pearson Correlation, yaitu dengan cara menghitung korelasi antara nilai yang diperole. Apabila nilai signifikan yang didapat dibawah 0,05 maka data yang di peroleh adalah valid.

\section{Uji Reliabilitas}

Uji realibilitas ini dilakukan dengan menggunakan bantuan program SPSS, yang akan memberikan fasilitas untuk mengukur realibilitas dengan uji statistic Cronbach Alpha. Syarat minimum yang dianggap memenuhi syarat adalah apabila koefisien alpha cronbach's yang didapat 0,6 . Jika koefisien yang didapat kurang dari 0,6 maka instrumen penelitian tersebut dinyatakan tidak reliabel. Apabila dalam uji coba instrumen ini sudah valid dan reliabel, maka dapat digunakan untuk pengukuran dalam rangka pengumpulan data (Sugiyono, 2009).

\section{Uji Asumsi Klasik}

Tujuan penggunaan dari Uji Asumsi Klasik adalah agar diperoleh estimator tidak bias dari regresi dengan kuadrat terkecil.

\section{Uji Normalitas}

Tujuan uji normalitas adalah untuk menguji apakah dalam model regresi variabel bebas dan variabel terikat mempunyai distribusi normal atau tidak ( Ghozali, 2013). Regresi yang baik adalah jika data normal atau mendekati normal. Jika data menyebar searah dengan garis diagonal maka dapat memenuhi asumsi normalitas, jika data menyebar jauh dari garis diagonal maka model regresi tidak memenuhi asumsi normalitas. Apabila sebaran data pada grafik berada disekitar garis diagonal dan arah penyebarannya mengikuti arah garis diagonal berarti data berdistribusi normal.

\section{Uji Multikolinearitas}

Multikoliniaritas adalah gejala adanya hubungan linier yang sempurna (sangat kuat) diantara varibal bebas yang dianalisis. Model regresi mengasumsikan tidak adanya multikolinearitas atau tidak adanya hubungan (korelasi) yang sempurna antara variabel bebas satu dengan variabel yang lain, salah satu cara digunakan untuk mendeteksi adanya multikonearitas dengan cara melihat nilai Variance Inflation Faktor (VIF) masing-masing varibael bebas, dimana jika nilai terdapat VIF $>5$ maka terdapat gejala multikolienritas atau sebaliknya jika nilai terdapat VIF $<5$ maka tidak terjadi multikoleneritas, (Sarwoko,2018). 


\section{Uji Heterokedasitas}

Uji Heteroskedastisitas dilakukan dengan menggunakan grafik scatter plot. Deteksi heteroskedastisitas yaitu dengan melihat ada tidaknya pola tertentu pada grafik hasil analisis.Jika ada pola titik-titik yang membentuk gelembung menyebar maka telah terjadi heteroskedastisitas.Jika titik-titik menyebar secara acak dan tidak membentuk suatu pola tertentu yang jelas, serta tersebar baik di atas maupun di bawah angka 0 pada sumbu $Y$ hal ini berarti tidak terjadi heteroskedastisitas atau data homogen.

\section{Analisis Regresi Linear Berganda}

Analisis regresi linear berganda digunakan untuk mengetahui seberapa besar pengaruh variabel bebas yaitu penerapan anggaran berbasis kinerja (X1), akuntabilita (X2) dan transparansi (X3) terhadap kinerja keuangan daerah (Y). Hasil analisis terlihat dalam tabel berikut:

Tabel 4.10 Analisis Regresi Linear Berganda

\begin{tabular}{|c|c|c|c|c|c|}
\hline \multirow[t]{2}{*}{ Variabel Independen } & \multicolumn{2}{|c|}{$\begin{array}{l}\text { Unstandardized } \\
\text { Coefficients }\end{array}$} & \multirow[t]{2}{*}{ Beta } & \multirow[t]{2}{*}{$\mathrm{t}$-hitung } & \multirow[t]{2}{*}{ Sign. T } \\
\hline & $\mathrm{B}$ & Std.Error & & & \\
\hline (Constant) & 7,652 & 7,617 & & 1,005 & 0,321 \\
\hline $\begin{array}{l}\text { Penerapan anggaran } \\
\text { berbasis kinerja(X1) }\end{array}$ & 0,464 & 0,131 & 0,460 & 3,557 & 0,001 \\
\hline Akuntabilitas (X2) & 0,713 & 0,322 & 0,333 & 2,219 & 0,032 \\
\hline Transparansi (X3) & 0,064 & 0,204 & 0,047 & 0,311 & 0,757 \\
\hline R Square $\left(\mathrm{R}^{2}\right)$ & 0,344 & & & & \\
\hline Adjusted R Square & 0,294 & & & & \\
\hline F- hitung & 6,981 & & & & \\
\hline Sign-F & 0,001 & & & & \\
\hline
\end{tabular}

Dari tabel diatas menunjukkan persamaan regresi sebagai berikut :

$\mathrm{Y}=7,652+0,464 \mathrm{X} 1+0,713 \mathrm{X} 2+0,064 \mathrm{X} 3+\mathrm{e}$

Persamaan regresi tersebut, diketahui bahwa :

1. Nilai konstanta sebesar 7,652 memiliki arti bahwa jika tidak ada variabel Penerapan anggaran berbasis kinerja (X1), Akuntabilitas (X2), Transparansi (X3), maka Kinerja keuangan (Y) sebesar 7,652 atau sangat tinggi.

2. Koefisien regresi variabel Penerapan anggaran berbasis kinerja (X1) mempunyai nilai $\beta$ (Undstandardized Coeffisients) sebesar 0,464 yang artinya jika variabel penerapan anggaran berbasis kinerja ditingkatkan kenaikannya, maka variabel kinerja keuangan daerah (Y) akan mengalami kenaikan dengan asumsi variabel lain bernilai tetap atau tidak berubah.

3. Koefisien regresi variabel Akuntabilitas (X2) mempunyai nilai $\beta$ (Undstandardized Coeffisients) sebesar 0,713 yang artinya jika variabel akuantabilitas ditingkatkan kenaikannya, maka variabel kinerja keuangan daerah (Y) akan mengalami kenaikan dengan asumsi variabel lain bernilai tetap atau tidak berubah.

4. Koefisien regresi variabel Transparansi (X3) mempunyai nilai $\beta$ (Undstandardized 
Coeffisients) sebesar 0,064 yang artinya jika variabel transparansi ditingkatkan kenaikannya, maka variabel kinerja keuangan daerah (Y) akan mengalami kenaikan dengan asumsi variabel lain bernilai tetap atau tidak berubah.

\section{Uji F (Uji Simultan)}

Uji F digunakan untuk menguji pengaruh variabel bebas secara simultan terhadap variabel terikat. Dilihat dari tabel 4.10 dan kriteria pengujiannya menyatakan bahwa nilai Fhitung sebesar 6,981 dengan signifikan sebesar 0,001, berarti signifikan $F_{\text {hitung }}<0,05$ menunjukkan bahwa variabel Penerapan anggaran berbasis kinerja (X1), Akuntabilitas (X2) dan Transparansi (X3) secara bersama-sama berpengaruh signifikan terhadap Kinerja keuangan daerah (Y). Hasil uji $\mathrm{F}$ juga menunjukkan bahwa model regresi dapat menjelaskan pengaruh variabel bebas penerapan anggaran berbasis kinerja, akuntabilitas dan transparansi terhadap kinerja keuangan daerah.

\section{Uji Koefisien Determinasi $\left(\mathbf{R}^{2}\right)$}

Koefisien determinasi digunakan untuk mengetahui prosentase besarnya perubahan variabel terikat (dependen) yang disebabkan oleh variabel bebas (independen). Tabel 4.10 menunjukkan bahwa nilai koefisien determinasi (R Square) sebesar 0,344 yang memiliki makna bahwa penerapan anggaran berbasis kinerja (X1), akuntabilitas (X2), dan transparansi (X3) mampu memberikan kontribusi 34,4\% terhadap kinerja keuangan daerah (Y), sisanya sebesar 65,6\% ditentukan oleh variabel lain yang belum di teliti.

\section{Uji Hipotesis}

Uji hipotesis penelitian ini menggunakan uji t. Uji -t digunakan untuk menguji signifikan pengaruh variabel independen secara parsial terhadap variabel dependen dengan menganggap variabel lain bersifat konstan. Dari hasil analisis regresi linier berganda pada tabel 4.10 diatas terlihat bahwa :

1) Uji hipotesis 4 (Penerapan anggaran berbasis kinerja, akuntabilitas dan transparansi secara simultan berpengaruh terhadap kinerja keuangan daerah Kota Malang), Hasil uji regresi menunjukkan bahwa variabel penerapan anggaran berbasis kinerja (X1), akuntabilitas (X2) dan transparansi (X3) menunjukkan nilai signifikan t sebesar 0,001 > 0,05 berarti secara bersama-sama berpengaruh signifikan terhadap variabel kinerja keuangan daerah (Y). Dengan demikian dapat disimpulkan bahwa hipotesis 4 dapat diterima.

2) Uji hipotesis 1 (Penerapan anggaran berbasis kinerja berpengaruh terhadap kinerja keuangan daerah Kota Malang), Hasil uji regresi menunjukkan bahwa variabel penerapan anggaran berbasis kinerja (X1) menunjukkan nilai signifikan $t$ sebesar $0,001>0,05$, berarti ada pengaruh yang signifikan dari variabel penerapan anggaran berbasis kinerja (X1) terhadap variabel kinerja keuangan daerah (Y). Dengan demikian dapat disimpulkan bahwa hipotesis 1dapat diterima.

3) Uji hipotesis 2 (Akuntabilitas berpengaruh terhadap kinerja keuangan daerah Kota Malang), Hasil uji regresi menunjukkan bahwa variabel akuntabilitas (X2) menunjukkan nilai signifikan $t$ sebesar 0,032>0,05, berarti ada pengaruh yang signifikan dari variabel akuntabilitas (X2) terhadap variabel kinerja keuangan daerah (Y). Dengan demikian dapat disimpulkan bahwa hipotesis 2 dapat diterima.

4) Uji hipotesis 3 (Transparansi berpengaruh terhadap kinerja keuangan daerah Kota Malang), Hasil uji regresi menunjukkan bahwa variabel transparansi (X3) menunjukkan nilai signifikan $\mathrm{t}$ sebesar $0,757>0,05$, berarti tidak ada pengaruh yang signifikan dari variabel transparansi (X3) terhadap variabel kinerja keuangan daerah (Y). Dengan demikian dapat disimpulkan bahwa hipotesis 3 tidak dapat diterima. 


\section{Pengaruh Penerapan Anggaran Berbasis Kinerja Terhadap Kinerja Keuangan Daerah}

Berdasarkan hasil uji regresi dalam penelitian ini bahwa variabel penerapan anggaran berbasis kinerja berpengaruh secara signifikan terhadap kinerja keuangan daerah pada Badan Pengelolaan Keuangan dan Aset Daerah Kota Malang. Hasil penelitian ini sesuai dengan pendapat Robinson, 2009) yang menyatakan bahwa tujuan anggaran berbasis kinerja adalah untuk meningkatkan efisiensi dan efektivitas pengeluaran publik dengan mengaitkan pendanaan organisasi sektor publik dengan hasil yang dicapai dengan penggunan informasi kinerja secara sistematik. Hijrani Putri Lubis (2009) berdasarkan hasil uji hipotesis dan analisis regresi menunjukkan bahwa variabel anggaran berbasis kinerja memilik pengaruh terhadap kinerja keuangan pemerintah daerah. Berdasarkan uji hipotesis bahwa penerapan anggaran berbasis kinerja memiliki pengaruh yang positif dan signifikan terhadap kinerja keuangan pemerintah daerah. Berdasarkan hasil penelitian maka peningkatan kinerja keuangan daerah Kota Malang bisa dilakukan melalui penerapan anggaran berbasis kinerja melalui peningkatan pencapaian tujuan, efektivitas, dan efisiensi . Kinerja keuangan bisa meningkat apabila suatu tujuan yang telah ditetapkan tercapai, begitu pula sebalikya.

\section{Pengaruh Akuntabilitas Terhadap Kinerja Keuangan Daerah}

Berdasarkan hasil analisis data dalam penelitian ini menunjukkan bahwa ada pengaruh yang signifikan antara akuntabilitas terhadap kinerja keuangan pada Pemerintah Kota Malang. Hal ini dapat dibuktikan dari hasil analisis uji t didapatkan statistik uji $t$ sebesar 2,219 dengan tingkat signifikan sebesar 0,032. Karena tingkat signifikannya lebih kecil dari 0,05, maka variabel akuntabilitas berpengaruh terhadap variabel kinerja keuangan daerah . Sehingga H1 diterima dan H0 ditolak.Akuntabilitas mampu mempengaruhi kinerja keuangan daerah karena akuntabilitas sebagai alat untuk mencapai tujuan instansi pemerintah daerah dengan cara meningkatkan pertanggungjawaban pemerintah terhadap masyarakat yang membutuhkan informasi terkait pengelolaan keuangan daerah tersebut. Jika pemerintah mampu menerapkan pertanggung jawabannya dengan baik, atau mengelola keuangan daerah dengan terbuka terhadap masyarakatnya, maka kinerja keuangan pun meningkat. Begitu pula sebaliknya, jika pemerintah tidak mengelola keuangannya dengan baik, atau tidak bertanggung jawab penuh terhadap orang yang membutuhkan informasi keuangan tersebut, maka kinerja keuangan pun menurun. Nadia Garini (2011) dalam hasil penelitiannya menyatakan bahwa akuntabilitas dan transparansi berpengaruh terhadap kinerja keuangan pemerintah daerah. Berdasarkan hasil penelitian maka peningkatan kinerja keuangan daerah Kota Malang bisa dilakukan melalui akuntabilitas melalui peningkatan pertanggung jawaban aparatur pemerintah terhadap masyarakat yang membutuhkan informasi mengenai keuangan daerah. Kinerja keuangan bisa meningkat apabila pertanggung jawaban pemerintah sepenuhnya diterapkan dengan baik. begitu pula sebalikya. Faktor lain yang dapat mempengaruhi kinerja keuangan adalah efektivitas dan efisien dalam pengelolaan keuangan daerah tersebut. Jika pengelolaan keuangan suatu daerah dilakukan secara efisien dan efektivitas maka kinerja keuangan pun meningkat. Hal ini sangat dibutuhkan agar pengelolaan keuangan pemerintah sesuai dengan anggaran yang telah ditetapkan.

\section{Pengaruh Transparansi Terhadap Kinerja Keuangan Daerah}

Berdasarkan hasil analisis data dalam penelitian ini menunjukkan bahwa tidak ada pengaruh yang signifikan antara akuntabilitas terhadap kinerja keuangan pada Pemerintah Kota Malang. Hal ini dapat dibuktikan dari hasil analisis uji $t$ didapatkan statistik uji $\mathrm{t}$ sebesar 0,311 dengan tingkat signifikan sebesar 0,757. Karena tingkat signifikannya lebih besar dari 0,05, maka variabel transparansi tidak berpengaruh 
terhadap variabel kinerja keuangan daerah. Sehingga H1 ditolak dan H0 diterima. Transparansi bukanlah menjadi tolak ukur yang pasti untuk menilai kinerja keuangan pemerintah daerah, walaupun dengan adanya transparansi atau keterbukaan dalam memberikan informasi keuangan tetapi tidak sepenuhnya dapat meningkatkan kinerja keuangan. Astuti (2013) dalam hasil penelitiannya menyatakan bahwa transparansi tidak berpengaruh terhadap kinerja keuangan pemerintah daerah. Berdasarkan hasil penelitian maka peningkatan kinerja keuangan daerah Kota Malang tidak sepenuhnya dilakukan melalui transparansi. Walaupun dalam suatu instansi pemerintah menetapkan transparansi, tetapi tidak sepenuhnya dapat meningkatkan kinerja keuangan daerah. Faktor lain yang dapat mempengaruhi kinerja keuangan adalah efektivitas dan efisien dalam pengelolaan keuangan daerah tersebut. Jika pengelolaan keuangan suatu daerah dilakukan secara efisien dan efektivitas maka kinerja keuangan pun meningkat. Hal ini sangat dibutuhkan agar pengelolaan keuangan pemerintah sesuai dengan anggaran yang telah ditetapkan. Faktor lain juga yang dapat mempengaruhi kinerja keuangan adalah dilihat dari kinerja individu yang mengelola keuangan daerah. Jika kinerja individu tersebut baik dan dapat memahami keuangan daerah, maka kinerja keuangan pun meningkat.

\section{Pengaruh Penerapan Anggaran Berbasis Kinerja, Akuntabilitas dan Transparansi Terhadap Kinerja Keuangan Daerah}

Berdasarkan hasil uji regresi dalam penelitian ini bahwa variabel penerapan anggaran berbasis kinerja, akuntabilitas dan transparansi secara simultan berpengaruh terhadap kinerja keuangan pada Badan Pengelolaan Keuangan dan Aset Daerah Kota Malang. Penerapan anggaran berbasis kinerja, akuntabilitas dan transparansi mampu mempengaruhi kinerja keuangan daerah karena peran anggaran berbasis kinerja adalah sebagai salah satu indikator kinerja keuangan pemerintah daerah, sedangkan akuntabilitas dan transparansi dierlukan karena aparatur harus mempertanggungjawabkan perbuatannya kepada masyarakat serta memberikan informasi yang terbuka mengenai pengelolaan keuangan instansi pemerintah. Syahrial Rambe (2013) yang menyatakan bahwa penerapan anggaran berbasis kinerja, akuntabilitas dan transparansi secara simultan berpengaruh terhadap kinerja keuangan pemerintah daerah. Berdasarkan hasil penelitian maka peningkatan kinerja keuangan daerah Kota Malang bisa dilakukan melalui penerapan anggaran berbasis kinerja, akuntabilitas dan transparansi melalui peningkatan pencapaian tujuan, efektivitas, efisiensi, keterbukaan dan pertanggungjawaban. Kinerja keuangan bisa meningkat apabila suatu tujuan yang telah ditetapkan tercapai. Kinerja keuangan juga bisa meningkat apabila pemerintah atau pimpinan dapat memberikan informasi yang terbuka terkait keuangan daerah dan bisa mempertanggungjawabkannya kepada publik yang membutuhkan informasi tersebut.

\section{Kesimpulan}

Berdasarkan hasil penelitian yang telah dijelaskan pada bab sebelumnya tentang Analisis Pengaruh Penerapan Anggaran Berbasis Kinerja, Akuntabilitas dan Transparansi Terhadap Kinerja Keuangan Daerah Kota Malang, maka dapat disimpulkan bahwa berdasarkan analisis regresi linear berganda ternyata hasil penelitian membuktikan bahwa variabel penerapan anggaran berbasis kinerja (independen) mempunyai pengaruh signifikan terhadap variabel dependen yaitu kinerja keuangan daerah Kota Malang. Penerapan anggaran berbasis kinerja juga dibentuk olehindikator input, output, outcome, benefit dan impact. Hal ini menunjukkan bahwa penerapan anggaran berbasis kinerja dapat meningkatkan kinerja keuangan daerah.

Berdasarkan analisis regresi linear berganda ternyata hasil penelitian membuktikan bahwa variabel akuntabilitas (independen) mempunyai pengaruh terhadap 
variabel dependen yaitu kinerja keuangan daerah Kota Malang. Akuntabilitas jugadibentuk oleh indikator kepatuhan terhadap hukum, pelayanan yang cepat dan pencapaian tujuan yang optimal dengan biaya yang minimal. Hal ini menunjukkan bahwa akuntabilitas dapat meningkatkan kinerja keuangan daerah.

Berdasarkan analisis regresi linear berganda ternyata hasil penelitian membuktikan bahwa variabel transparansi (independen) tidak mempunyai pengaruh terhadap variabel dependen yaitu kinerja keuangan daerah Kota Malang.Dapat disimpulkan bahwa transparansi yang kurang baik dapat menurunkan kinerja keuangan daerah.

Berdasarkan analisis regresi linear berganda ternyata hasil penelitian membuktikan bahwa variabel penerapan anggaran berbasis kinerja (independen), akuntabilitas (independen) dan transparansi(independen) secara bersama-sama mempunyai pengaruh terhadap variabel dependen yaitu kinerja keuangan daerah Kota Malang. Hal ini menunjukkan bahwa penerapan anggaran berbasis kinerja, akuntabilitas dan transparansi dapat meningkatkan kinerja keuangan daerah.

\section{Saran}

Saran yang diberikan peneliti secara akademik yaitu penelitian ini diharapkan dapat memberikan informasi dan kontribusi bagi pengembangan teori penerapan anggaran berbasis kinerja, akuntabilitas dan transparansi dalam meningkatkan kinerja keuangan daerah, dan secara praktisi manfaat yang diberikan kepada instansi yaitu untuk meningkatkan kinerja keuangan daerah perlu diperhatikan penerapan anggaran berbasis kinerja, akuntabilitas dan transparansi.

Hal yang perlu diperhatikan dalam meningkatkan kinerja keuangan daerah yaitu transparansi dimana transparansi merupakan hal yang sangat penting dalam pengelolaan keuangan daerah karena transparansi merupakan keterbukaan pemerintah kepada publik tentang semua informasi yang berkaitan dengan aktivitas penyelenggaraan pemerintah. Dalam hal ini pemerintah daerah Kota Malang perlu meningkatkan transparansi melalui peningkatan sistem keterbukaan kebijakan anggaran, laporan pertanggungjawaban yang tepat waktu dan sistem pemberian informasi kepada publik

Saran yang diberikan untuk peneliti selanjutnya yaitu disarankan untuk menambah instrumen penelitian yang digunakan dalam pengumpulan data, seperti observasi dan wawancara karena metode pengumpulan data melalui kuesioner sering menimbulkan masalah, serta menambah beberapa variabel independen lain sehingga dapat diketahui bahwa kinerja keuangan daerah juga dipengaruhi oleh variabel-variabel independen lain yang tidak tercakup dalam penelitian ini.

\section{Daftar Pustaka}

Anggraini, Y. D. (2010). Anggaran Berbasis Kinerja, Penyusunan APBD Secara Komprehensif. Jurnal Ilmiah, Vol. 3 No. 11 Februari 2010.

Darwanis. (2013). Akuntabilitas Kinerja Instansi Pemerintah. Jurnal Telaah dan Riset Akuntansi, Vol. 6 No. 2 Juli 2012.

Departemen Keuangan Republik Indonesia, Pedoman Penerapan Penganggaran Berbasis Kinerja (PBK) Tahun 2009.

Dwiputriati, Septiana dan Suharsini,. (2012). Analisis Penerapan Anggaran Berbasis Kinerja (ABK) terhadap Efisiensi, Efektivitas dan Akuntabilitas pada Pusat Pelatihan dan Pendidikan dan Pelatihan Kementrian Dalam Negeri Regional Bandung. Jurnal Ilmu 
Administrasi Vol IX Nomor 3, Desember 2012.

Eka, Dita. (2009). Analisis Pemberlakuan Anggaran Berbasis Kinerja Terhadap Kinerja Keuangan Pemerintah Kota Batu.

Espinoza. (2014). Pengaruh Penerapan Anggaran Berbasis Kinerja Terhadap Kinerja Keuangan Pemerintah Kota Pada Pemerintah Kota Medan.

Isti'anah. (2010). Penerapan dan Implementasi Anggaran Berbasis Kinerja. Jurnal Informasi, Perpajakan, Akuntansi dan Keuangan Publik, Vol 5. No. 1 Januari, 2010 Hal. $73-$ 84.

Jurusan Akuntansi, Fakultas Ekonomika dan Bisnis Universitas Kanjuruhan Malang. 2018. Buku Pedoman Penulisan Skripsi : Universitas Kanjuruhan Malang.

Kurniawan, Chandra. (2012). Analisis Pengaruh Pemberlakuan Anggaran Berbasis Kinerja Terhadap Kinerja Keuangan Daerah Kota Metro.

Kurrohman, T. 2013. Evaluasi Penganggaran Berbasis Kinerja Melalui Kinerja Keuangan Yang Berbasis Value For Money Di Kabupaten/Kota Di Jawa Timur. Jurnal Dinamika Akuntansi : Vol. 5, No. 1, Maret, PP.1-11

Lubis, Hijrani Putri. (2009). Analisis Pemberlakuan Anggaran Berbasis Kinerja Terhadap Kinerja Keuangan Pemerintah Daerah Kabupaten Deli Serdang. Skripsi Akuntansi, Universitas Sumatera Utara.

Mardiasmo.(2010). “Pengawasan, Pengendalian, Dan Pemeriksaan Kinerja Pemerintah Daerah Dalam Pelaksanaan Otonomi Daerah".Jurnal Bisnis dan Akuntansi. Vol 3, No.2:441-

456.http://ejournal.unsrat.ac.id/index.php/emba/article/view/2651/2204. Diakses pada 4 November 2018. Hal. 202-212.

Mardiasmo. (2013). Akuntansi Sektor Publik. Andi. Yogyakarta.

Mamuka, dkk.(2014).Pengertia Dana Perimbangan.JurnalAkuntansi Vol.3 No.2 (2014).

Patiruhu, dkk. (2018). Analisis Pengaruh Anggaran Berbasis Kinerja Terhadap Kinerja Aparatur Pemerintah. Jurnalsosoq, Vol. 6, No. 01, Februari 2018

Patiruhu, J. R. (2018). Analisis Pengaruh Anggaran Berbasis Kinerja Terhadap Kinerja Manajerial Aparatur Pemerintah.

Peraturan Mentri Dalam Negri Nomor 21 Tahun 2011 Tentang Pedoman Pengelolaan Keuangan Daerah.

Nanda, Reza. (2016). Analisis Implementasi Anggaran Berbasis Kinerja Pada Pemerintah Daerah Kabupaten Aceh Selatan,Jurnal Ilmiah Mahasiswa Ekonomi Akuntansi Vol. 1 No. 1

Safrudin, Lian. (2016). Pengaru Penerapan Anggaran Berbasis Kinerja Terhadap Kinerja InstansiPemerintah Daerah.

Sarwoko (2011), Statistik Inferensi untuk Ekonomi dan Bisnis. Penerbit Andi: Yogyakarta.

Sarwono, J. (2006). Analisis Data Penelitian Menggunakan SPSS. Yogyakarta: C.V ANDI OFFSET. 